\title{
Isoptericola dokdonensis sp. nov., isolated from soil
}

\author{
Jung-Hoon Yoon, ${ }^{1}$ Peter Schumann, ${ }^{2}$ So-Jung Kang, ${ }^{1}$ Seo-Youn Jung ${ }^{1}$ \\ and Tae-Kwang $\mathrm{Oh}^{1}$ \\ ${ }^{1}$ Korea Research Institute of Bioscience and Biotechnology (KRIBB), Laboratory of Microbial \\ Function, PO Box 115, Yusong, Taejon, Korea \\ ${ }^{2} \mathrm{DSMZ}$ - Deutsche Sammlung von Mikroorganismen und Zellkulturen GmbH, Mascheroder \\ Weg 1b, D-38124 Braunschweig, Germany
}

\begin{abstract}
A Gram-positive, non-motile, rod- or coccoid-shaped /soptericola-like bacterium, strain DS-3 ${ }^{\top}$, was isolated from a soil sample from Dokdo, Korea, and its taxonomic position was investigated by a polyphasic approach. The organism grew optimally at $30{ }^{\circ} \mathrm{C}$ and $\mathrm{pH} 7 \cdot 0-8 \cdot 0$. Strain $\mathrm{DS}-3^{\top}$ had the peptidoglycan type based on L-Lys-D-Asp, and galactose, glucose, rhamnose and ribose as the whole-cell sugars. It contained $\mathrm{MK}-9\left(\mathrm{H}_{4}\right)$ as the predominant menaquinone and anteiso- $\mathrm{C}_{15: 0}$ and iso- $\mathrm{C}_{15: 0}$ as the major fatty acids. The major polar lipids were diphosphatidylglycerol, phosphatidylglycerol, phosphatidylinositol and two unidentified glycolipids. The DNA G+C content was $74 \cdot 1 \mathrm{~mol} \%$. Phylogenetic analysis based on $16 \mathrm{~S}$ rRNA gene sequences showed that strain DS- $3^{\top}$ was most closely related to members of the genus /soptericola. Similarity values between the $16 \mathrm{~S}$ rRNA gene sequences of strain DS $-3^{\top}$ and the type strains of /soptericola species ranged from $98 \cdot 0$ to $98 \cdot 4 \%$. DNA-DNA relatedness values (11-23\%) and differential phenotypic properties demonstrated that strain $\mathrm{DS}-3^{\top}$ was distinguishable from recognized /soptericola species. On the basis of phenotypic properties and phylogenetic and genetic distinctiveness, strain DS $-3^{\top}$ represents a novel species in the genus Isoptericola, for which the name Isoptericola dokdonensis sp. nov. is proposed. The type strain is DS-3 ${ }^{\top}\left(=\operatorname{KCTC} 19128^{\top}=\right.$ CIP $\left.108921^{\top}\right)$.
\end{abstract}

The genus Isoptericola was proposed by reclassification of Cellulosimicrobium variabile (Bakalidou et al., 2002) as Isoptericola variabilis (Stackebrandt et al., 2004). Currently, the genus Isoptericola comprises three species with validly published names: Isoptericola variabilis (Stackebrandt et al., 2004), Isoptericola hypogeus (Groth et al., 2005) and Isoptericola halotolerans (Zhang et al., 2005). In this study, we report on the taxonomic characterization of an Isoptericola-like bacterial strain, DS- $3^{\mathrm{T}}$, which was isolated from a soil sample from Dokdo in Korea.

Strain DS $-3^{\mathrm{T}}$ was isolated using the standard dilution plating technique at $25^{\circ} \mathrm{C}$ on nutrient agar (Difco). The type strains of three Isoptericola species were used as reference strains: $I$. variabilis DSM $10177^{\mathrm{T}}$ and I. hypogeus DSM $16849^{\mathrm{T}}$ were obtained from the DSMZ (Braunschweig, Germany) and I. halotolerans KCTC $19046^{\mathrm{T}}$ was obtained from the Korean Collection for Type Cultures (Taejon, Korea). The morphological, physiological and biochemical characteristics of strain DS $-3^{T}$ were investigated using routine cultivation on trypticase soy agar (TSA; Difco) at $30^{\circ} \mathrm{C}$. Cell morphology was examined by light microscopy (Nikon E600) and

The GenBank/EMBL/DDBJ accession number for the $16 \mathrm{~S}$ rRNA gene sequence of strain DS-3 ${ }^{\top}$ is $\mathrm{DO} 387860$. transmission electron microscopy. The presence of flagella was determined by transmission electron microscopy using cells from exponentially growing cultures. For transmission electron microscopic observation, cells were negatively stained with $1 \%(\mathrm{w} / \mathrm{v})$ phosphotungstic acid and the grids were air-dried and examined with a Philips CM-20 transmission electron microscope. The Gram reaction was determined using the bioMérieux Gram stain kit according to the manufacturer's instructions. Growth at various temperatures $\left(4-45^{\circ} \mathrm{C}\right)$ was measured on TSA. To investigate tolerance of $\mathrm{NaCl}$, trypticase soy broth was prepared according to the formula of the Difco medium and $\mathrm{NaCl}$ concentrations were varied $(0,0.5$ and $1 \cdot 0-10 \cdot 0 \%, \mathrm{w} / \mathrm{v}$, at intervals of $1 \cdot 0 \%)$. The $\mathrm{pH}$ range for growth was determined in nutrient broth (Difco) adjusted to various $\mathrm{pH}$ values ( $\mathrm{pH} 4 \cdot 5-10 \cdot 5$ at intervals of $0.5 \mathrm{pH}$ units) prior to sterilization by the addition of $\mathrm{HCl}$ or $\mathrm{Na}_{2} \mathrm{CO}_{3}$. Growth under anaerobic conditions was determined after incubation in an anaerobic chamber on TSA and on TSA supplemented with nitrate. Catalase and oxidase activities and hydrolysis of casein, gelatin, hypoxanthine, starch, Tweens 20, 40, 60 and 80, tyrosine, urea and xanthine were determined as described by Cowan \& Steel (1965). Hydrolysis of aesculin and nitrate reduction was studied as described previously (Lanyi, 1987). Utilization of 
substrates as sole carbon and energy sources was tested according to the method of Kämpfer et al. (1991). Susceptibility to antibiotics was tested on TSA plates using antibiotic discs containing the following concentrations: polymyxin B, $100 \mathrm{U}$; streptomycin, $50 \mu$;; penicillin G, $20 \mathrm{U}$; chloramphenicol, $100 \mu \mathrm{g}$; ampicillin, $10 \mu \mathrm{g}$; cephalothin, $30 \mu \mathrm{g}$; gentamicin, $30 \mu \mathrm{g}$; novobiocin, $5 \mu \mathrm{g}$; tetracycline, $30 \mu \mathrm{g}$; kanamycin, $30 \mu \mathrm{g}$; lincomycin, $15 \mu \mathrm{g}$; oleandomycin, $15 \mu \mathrm{g}$; neomycin, $30 \mu \mathrm{g}$; carbenicillin, $100 \mu \mathrm{g}$. Other physiological properties and enzyme activities were tested using API 20E and API ZYM systems (bioMérieux).

Cell biomass for DNA extraction and for analyses of cell-wall components, isoprenoid quinones and polar lipids was obtained from cultures grown by shaking at 150 r.p.m. in trypticase soy broth (Difco) at $30^{\circ} \mathrm{C}$. Chromosomal DNA was isolated and purified according to the method described previously (Yoon et al., 1996), with the exception that RNase T1 was used in combination with RNase A to minimize contamination with RNA. The 16S rRNA gene was amplified by PCR using two universal primers as described previously (Yoon et al., 1998). Sequencing of the amplified $16 \mathrm{~S}$ rRNA gene and phylogenetic analysis were performed as described by Yoon et al. (2003). The DNA G + C content was determined by the method of Tamaoka \& Komagata (1984) with the modification that DNA was hydrolysed and the resultant nucleotides were analysed by reverse-phase HPLC. The presence or absence of diaminopimelic acid in the peptidoglycan was determined by the method described by Komagata \& Suzuki (1987). Preparation of cell walls and determination of peptidoglycan structure were carried out using modified methods of Schleifer \& Kandler (1972) and MacKenzie (1987). Whole-cell sugars were determined as described by Komagata \& Suzuki (1987). Isoprenoid quinones were extracted according to the method of Komagata \& Suzuki (1987) and analysed using reversephase HPLC on a YMC ODS-A $(250 \times 4.6 \mathrm{~mm})$ column. Polar lipids were extracted according to the procedures described by Minnikin et al. (1984) and identified by twodimensional TLC followed by spraying with appropriate detection reagents (Minnikin et al., 1984; Komagata \& Suzuki, 1987). For fatty acid methyl ester analysis, cell mass of strain DS- $3^{\mathrm{T}}$ was harvested from TSA plates after incubation for 3 days at $30^{\circ} \mathrm{C}$. The fatty acid methyl esters were extracted and prepared according to the standard protocol of the MIDI/Hewlett Packard Microbial Identification System (Sasser, 1990). DNA-DNA hybridization was performed fluorometrically by the method of Ezaki et al. (1989) using photobiotin-labelled DNA probes and microdilution wells. Hybridization was performed with five replications for each sample. The highest and lowest values obtained in each sample were excluded and the means of the remaining three values were quoted as DNA-DNA relatedness values.

The morphological, cultural, physiological and biochemical characteristics of strain DS- $3^{\mathrm{T}}$ are given in the species description (see below) or are shown in Table 1. The almost complete 16S rRNA gene sequence of strain DS- $3^{\mathrm{T}}$ determined in this study comprised $1474 \mathrm{nt}$, representing approximately $96 \%$ of the Escherichia coli $16 \mathrm{~S}$ rRNA gene sequence. Comparative $16 \mathrm{~S}$ rRNA gene sequence analysis showed that strain DS- $3^{\mathrm{T}}$ was most closely related to members of the genus Isoptericola. In a phylogenetic tree based on the neighbour-joining algorithm, strain DS- $3^{\mathrm{T}}$ joined the clade comprising Isoptericola species at a bootstrap confidence value of $85.0 \%$ (Fig. 1). Strain DS$3^{\mathrm{T}}$ exhibited $16 \mathrm{~S}$ rRNA gene sequence similarity values of $98 \cdot 0,98 \cdot 0$ and $98 \cdot 4 \%$ to the type strains of $I$. halotolerans, $I$. hypogeus and $I$. variabilis, respectively, and of less than $97 \cdot 6 \%$ to other species included in the phylogenetic analysis.

The total hydrolysate of the peptidoglycan of strain DS- $3^{\mathrm{T}}$ contained the amino acids alanine and glutamic acid and smaller amounts of lysine and aspartic acid. In addition, LLys-D-Asp was present, which is stable under conditions of total hydrolysis $\left(4 \mathrm{M} \mathrm{HCl}, 16 \mathrm{~h}\right.$ at $\left.100{ }^{\circ} \mathrm{C}\right)$. From quantitative analysis of the peptidoglycan amino acids by gas chromatography, strain DS- $3^{\mathrm{T}}$ contained alanine, aspartic acid, glutamic acid and lysine in an approximate ratio of $1 \cdot 4: 0 \cdot 3: 1 \cdot 0: 0 \cdot 2$. The reduced amounts of lysine and aspartic acid were due to the occurrence of the stable peptide L-Lys-D-Asp. From these data, it was concluded that strain DS- $3^{\mathrm{T}}$ showed the peptidoglycan type A4 $\alpha$, based on L-Lys-D-Asp, as described by Schleifer \& Kandler (1972). The peptidoglycan structure of strain DS- $3^{\mathrm{T}}$ was the same as that of I. variabilis and I. halotolerans, but different from that of I. hypogeus, which has the peptidoglycan type based on LLys-D-Glu (Stackebrandt et al., 2004; Groth et al., 2005; Zhang et al., 2005). Strain DS- $3^{\mathrm{T}}$ contained MK-9 $\left(\mathrm{H}_{4}\right)$, at peak area ratio of approximately $85 \%$, as the predominant menaquinone; smaller amounts (approx. 6-9\%) of MK$9\left(\mathrm{H}_{2}\right)$ and MK-8 $\left(\mathrm{H}_{4}\right)$ were also present. This menaquinone profile was similar to those of I. variabilis and I. halotolerans, but different from that of I. hypogeus, which has major amounts of MK-9 $\left(\mathrm{H}_{2}\right)$ and MK-9 and a minor amount of MK-9 $\left(\mathrm{H}_{4}\right)$ (Stackebrandt et al., 2004; Groth et al., 2005; Zhang et al., 2005). Major polar lipids detected in strain DS$3^{\mathrm{T}}$ were diphosphatidylglycerol, phosphatidylglycerol, phosphatidylinositol and two unidentified glycolipids. This polar lipid profile was similar to those of Isoptericola species, although it differed from that of I. hypogeus in that phosphatidylinositol mannoside was absent (Stackebrandt et al., 2004; Groth et al., 2005; Zhang et al., 2005). The fatty acid profile of strain DS- $3^{\mathrm{T}}$ comprised $(>0.5 \%$ of total fatty acids) branched fatty acids anteiso- $\mathrm{C}_{15: 0}(58 \cdot 6 \%)$, iso- $\mathrm{C}_{15: 0}$ $(11 \cdot 5 \%)$, iso- $\mathrm{C}_{14: 0}(4 \cdot 2 \%)$, anteiso- $\mathrm{C}_{17: 0}(4 \cdot 1 \%)$, iso$\mathrm{C}_{16: 0}(3 \cdot 0 \%)$, iso- $\mathrm{C}_{13: 0}(1 \cdot 1 \%)$ and iso- $\mathrm{C}_{17: 0}(0 \cdot 5 \%)$; and straight-chain fatty acids $\mathrm{C}_{16: 0}(9 \cdot 0 \%), \mathrm{C}_{14: 0}(3 \cdot 3 \%), \mathrm{C}_{15: 0}$ $(2 \cdot 6 \%)$ and $\mathrm{C}_{17: 0}(0.6 \%)$. This fatty acid profile was similar to those of Isoptericola species in that anteiso- $\mathrm{C}_{15: 0}$ was the major fatty acid (Stackebrandt et al., 2004; Groth et al., 2005; Zhang et al., 2005). The DNA G + C content of strain DS $-3^{\mathrm{T}}$ was $74 \cdot 1 \mathrm{~mol} \%$. Based on the results of the phylogenetic and chemotaxonomic analyses, it seems appropriate that strain 
Table 1. Differential phenotypic characteristics of strain $D S-3^{T}$ and /soptericola species

Species/strains: 1, strain DS-3 ${ }^{\mathrm{T}}$ (I. dokdonensis sp. nov.); 2, I. variabilis (unless indicated, data from Bakalidou et al., 2002; Groth et al., 2005; Zhang et al., 2005); 3, I. hypogeus (Groth et al., 2005); 4, I. halotolerans (Zhang et al., 2005). +, Positive; -, negative; W, weakly positive; ND, no data available; V, variable. All taxa are positive for Gram-staining, catalase (data from this study for I. hypogeus), nitrate reduction, hydrolysis of aesculin (data from this study for I. halotolerans), utilization of D-glucose, D-galactose, D-cellobiose, D-mannose, Dxylose, L-arabinose and salicin and activity of esterase (C4), esterase lipase (C8), leucine arylamidase, naphthol-AS-BI-phosphohydrolase, $\beta$ galactosidase, $\alpha$-glucosidase and $\beta$-glucosidase and are susceptible (data from this study) to neomycin $(30 \mu \mathrm{g})$, tetracycline $(30 \mu \mathrm{g})$ and chloramphenicol $(100 \mu \mathrm{g})$. All species are negative for motility, hydrolysis of Tween 80 (data from this study for $I$. hypogeus) and activity of $\alpha$-chymotrypsin, $\beta$-glucuronidase, $\alpha$-mannosidase and $\alpha$-fucosidase and are not susceptible (data from this study for I. halotolerans) to ampicillin $(10 \mu \mathrm{g})$ or kanamycin $(30 \mu \mathrm{g})$.

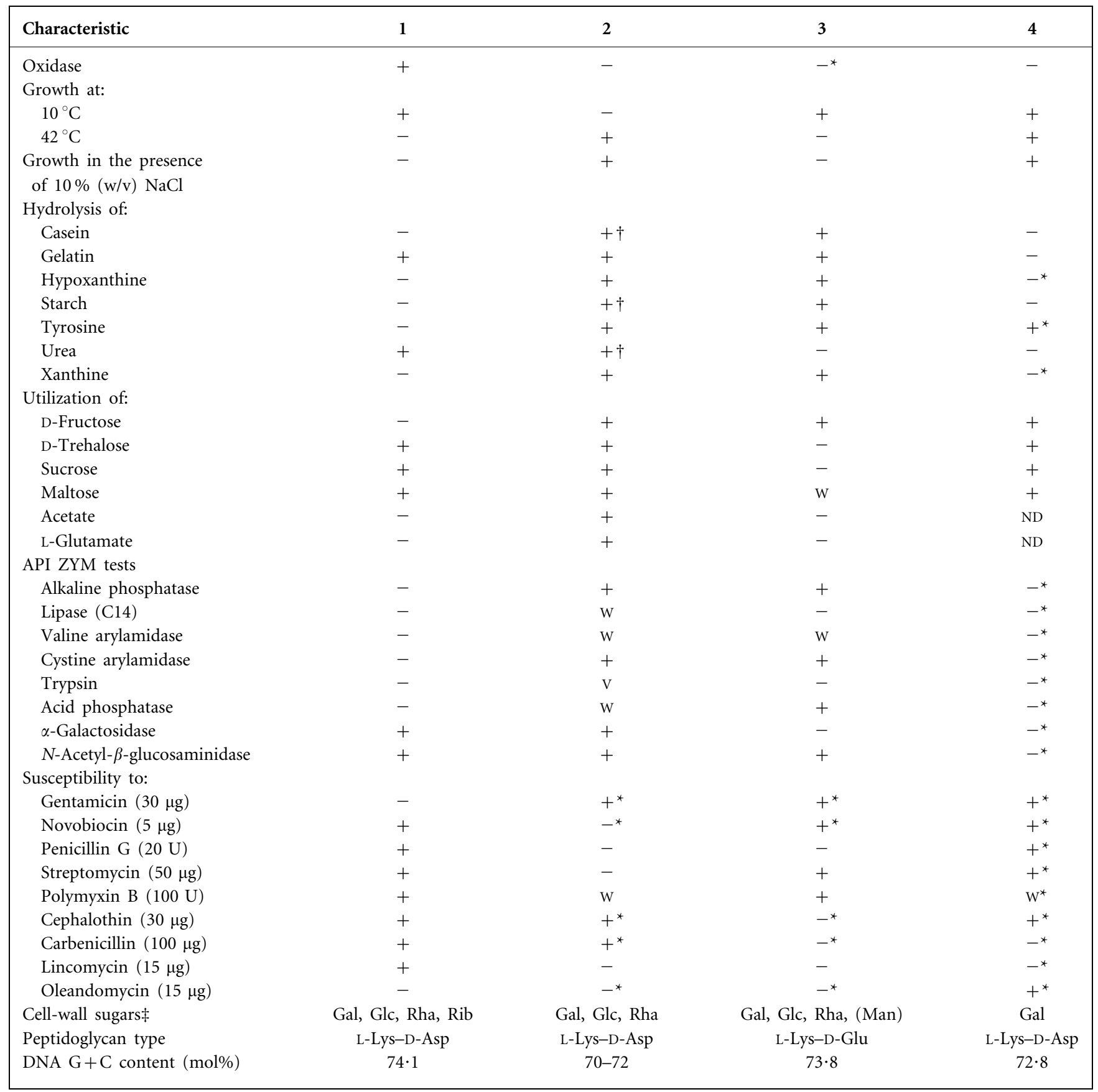

${ }^{*}$ Data for the type strain from this study.

$\dagger$ Data from Groth et al. (2005); the opposite result was reported by Zhang et al. (2005).

¥Abbreviations: Gal, galactose; Glc, glucose; Man, mannose; Rha, rhamnose; Rib, ribose. Minor components are indicated in parentheses. Data for strain DS- $3^{\mathrm{T}}$ and I. hypogeus were obtained from whole-cell hydrolysates. 


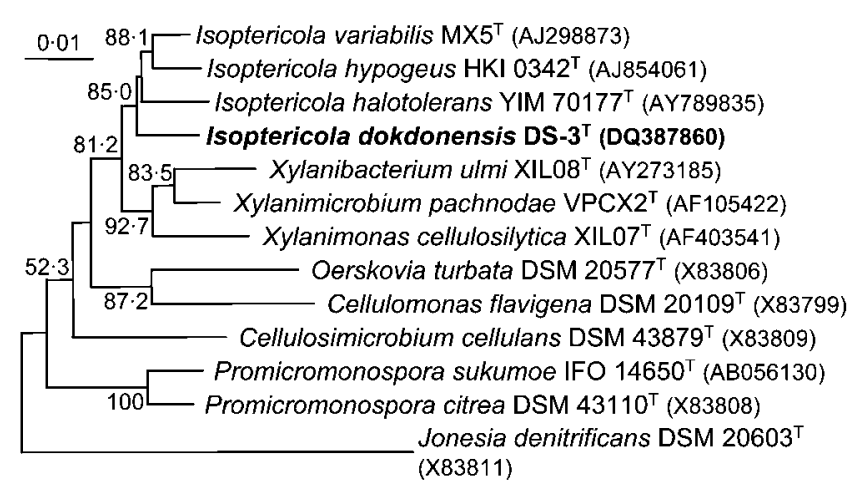

Fig. 1. Neighbour-joining phylogenetic tree based on $16 \mathrm{~S}$ rRNA gene sequences showing the positions of strain DS- ${ }^{T}$, Isoptericola species and some other related taxa. Bootstrap values (expressed as percentages of 1000 replications) of $>50 \%$ are shown at branch points. Jonesia denitrificans DSM $20603^{\top}$ was used as an outgroup. Bar, 0.01 substitutions per nucleotide position.

DS- $3^{\mathrm{T}}$ be considered as a member of the genus Isoptericola, although there are some differences in chemotaxonomic properties between strain DS- $3^{\mathrm{T}}$ and I. hypogeus (Stackebrandt et al., 2004; Groth et al., 2005; Zhang et al., 2005).

DNA-DNA relatedness data demonstrated that strain DS- $3^{\mathrm{T}}$ represents a genomic species that is different from recognized Isoptericola species (Wayne et al., 1987). Mean DNA-DNA relatedness values between strain DS- $3^{\mathrm{T}}$ and the type strains of the three recognized Isoptericola species were in the range of $11-23 \%$. Strain DS- $3^{\mathrm{T}}$ could also be distinguished from the three recognized Isoptericola species by noteworthy differences in several phenotypic properties as shown in Table 1. Therefore, on the basis of the data presented, strain DS- $3^{\mathrm{T}}$ should be placed in the genus Isoptericola within a novel species, for which the name Isoptericola dokdonensis sp. nov. is proposed.

\section{Description of Isoptericola dokdonensis sp. nov.}

Isoptericola dokdonensis (dok.do.nen'sis. N.L. masc. adj. dokdonensis of Dokdo, Korea, where the organism was first isolated).

Cells are Gram-positive, non-motile rods or cocci $(0 \cdot 8-1 \cdot 1 \times 0 \cdot 8-4 \cdot 5 \mu \mathrm{m})$. Primary mycelium is formed. Colonies on TSA are circular, convex, smooth, yellow in colour and $1.0-2.0 \mathrm{~mm}$ in diameter after 3 days of incubation at $30^{\circ} \mathrm{C}$. Optimal temperature for growth is $30^{\circ} \mathrm{C}$. Growth occurs at 10 and $40^{\circ} \mathrm{C}$, but not at 4 or $41^{\circ} \mathrm{C}$. Optimal $\mathrm{pH}$ for growth is between $7 \cdot 0$ and $8 \cdot 0$; growth occurs at $\mathrm{pH} 6 \cdot 5$, but not at $\mathrm{pH} 6 \cdot 0$. Growth occurs in the presence of $0-9 \%(\mathrm{w} / \mathrm{v}) \mathrm{NaCl}$. Anaerobic growth occurs on TSA and on TSA supplemented with nitrate. Tweens 20, 40 and 60 are not hydrolysed. $\mathrm{H}_{2} \mathrm{~S}$ and indole are not produced.
Arginine dihydrolase, lysine decarboxylase, ornithine decarboxylase and tryptophan deaminase are absent. Pyruvate is utilized as a carbon source, but benzoate, citrate, L-malate, succinate and formate are not. The cell-wall peptidoglycan type is L-Lys-D-Asp. The whole-cell sugars are galactose, glucose, rhamnose and ribose. The predominant menaquinone is MK- $9\left(\mathrm{H}_{4}\right)$. The major fatty acids ( $>10 \%$ of total fatty acids) are anteiso- $\mathrm{C}_{15: 0}$ and iso- $\mathrm{C}_{15: 0}$. The major polar lipids are diphosphatidylglycerol, phosphatidylglycerol, phosphatidylinositol and two unidentified glycolipids. The DNA G $+\mathrm{C}$ content is $74 \cdot 1 \mathrm{~mol} \%$ (determined by HPLC). Other phenotypic characteristics are given in Table 1.

The type strain, DS $-3^{\mathrm{T}}\left(=\right.$ KCTC $\left.19128^{\mathrm{T}}=\mathrm{CIP} 108921^{\mathrm{T}}\right)$, was isolated from soil in Dokdo, Korea.

\section{Acknowledgements}

This work was supported by the 21C Frontier program of Microbial Genomics and Applications (grant MG05-0401-2-0) from the Ministry of Science and Technology (MOST) of the Republic of Korea. We are grateful to the Ulleung County Administration and the Cultural Heritage Administration of the Republic of Korea for aiding access to Dokdo.

\section{References}

Bakalidou, A., Kämpfer, P., Berchtold, M., Kuhnigk, T., Wenzel, M. \& König, H. (2002). Cellulosimicrobium variabile sp. nov., a cellulolytic bacterium from the hindgut of the termite Mastotermes darwiniensis. Int J Syst Evol Microbiol 52, 1185-1192.

Cowan, S. T. \& Steel, K. J. (1965). Manual for the Identification of Medical Bacteria. London: Cambridge University Press.

Ezaki, T., Hashimoto, Y. \& Yabuuchi, E. (1989). Fluorometric deoxyribonucleic acid-deoxyribonucleic acid hybridization in microdilution wells as an alternative to membrane filter hybridization in which radioisotopes are used to determine genetic relatedness among bacterial strains. Int J Syst Bacteriol 39, 224-229.

Groth, I., Schumann, P., Schütze, B., Gonzalez, J. M., Laiz, L., Saiz-Jimenez, C. \& Stackebrandt, E. (2005). Isoptericola hypogeus sp. nov., isolated from the Roman catacomb of Domitilla. Int J Syst Evol Microbiol 55, 1715-1719.

Kämpfer, P., Steiof, M. \& Dott, W. (1991). Microbiological characterization of a fuel-oil contaminated site including numerical identification of heterotrophic water and soil bacteria. Microb Ecol 21, 227-251.

Komagata, K. \& Suzuki, K. (1987). Lipids and cell-wall analysis in bacterial systematics. Methods Microbiol 19, 161-203.

Lanyi, B. (1987). Classical and rapid identification methods for medically important bacteria. Methods Microbiol 19, 1-67.

MacKenzie, S. L. (1987). Gas chromatographic analysis of amino acids as the $N$-heptafluorobutyryl isobutyl esters. J Assoc Off Anal Chem 70, 151-160.

Minnikin, D. E., O'Donnell, A. G., Goodfellow, M., Alderson, G., Athalye, M., Schaal, A. \& Parlett, J. H. (1984). An integrated procedure for the extraction of bacterial isoprenoid quinones and polar lipids. J Microbiol Methods 2, 233-241.

Sasser, M. (1990). Identification of bacteria by gas chromatography of cellular fatty acids, Technical Note no. 101. Newark, DE: MIDI Inc. 
Schleifer, K. H. \& Kandler, O. (1972). Peptidoglycan types of bacterial cell walls and their taxonomic implications. Bacteriol Rev 36, 407-477.

Stackebrandt, E., Schumann, P. \& Cui, X.-L. (2004). Reclassification of Cellulosimicrobium variabile Bakalidou et al. 2002 as Isoptericola variabilis gen. nov., comb. nov. Int J Syst Evol Microbiol 54, 685-688.

Tamaoka, J. \& Komagata, K. (1984). Determination of DNA base composition by reverse-phase high-performance liquid chromatography. FEMS Microbiol Lett 25, 125-128.

Wayne, L. G., Brenner, D. J., Colwell, R. R. \& 9 other authors (1987), Report of the ad hoc committee on reconciliation of approaches to bacterial systematics. Int J Syst Bacteriol 37, 463-464.

Yoon, J.-H., Kim, H., Kim, S.-B., Kim, H.-J., Kim, W. Y., Lee,

S. T., Goodfellow, M. \& Park, Y.-H. (1996). Identification of
Saccharomonospora strains by the use of genomic DNA fragments and rRNA gene probes. Int $J$ Syst Bacteriol 46, 502-505.

Yoon, J.-H., Lee, S. T. \& Park, Y.-H. (1998). Inter- and intraspecific phylogenetic analysis of the genus Nocardioides and related taxa based on $16 \mathrm{~S}$ rDNA sequences. Int $J$ Syst Bacteriol 48, 187-194.

Yoon, J.-H., Kang, K. H. \& Park, Y.-H. (2003). Psychrobacter jeotgali sp. nov., isolated from jeotgal, a traditional Korean fermented seafood. Int J Syst Evol Microbiol 53, 449-454.

Zhang, Y.-Q., Schumann, P., Li, W.-J., Chen, G.-Z., Tian, X.-P., Stackebrandt, E., Xu, L.-H. \& Jiang, C.-L. (2005). Isoptericola halotolerans sp. nov., a novel actinobacterium isolated from saline soil from Qinghai Province, north-west China. Int J Syst Evol Microbiol 55, 1867-1870. 